\title{
The Influence of Outdoor Learning to Improve Children's Creativity
}

\author{
A. Fachrurrazi, Chrisdiana Kurniasari \\ Program Studi PGPAUD Universitas PGRI Adi Buana Surabaya, Surabaya, Indonesia \\ Corresponding e-mail: amangrozy@gmail.com
}

\begin{abstract}
This study is conducted to answer the research question "what the difference of study result of the children with use the models outdoor learning and indoor learning of the Early Chilhood' creativity". The background of this research while such by a lack of opportunities given by teachers to a child in understand the situation and conditions on when the are studying, that study results obtained less than maximum. The aim is to tell the difference of study result of the children with use the model outdoor learning and indoor learning in groups B TK Sartiasari Surabaya. This research used one group pretest posttest design that experiments done before the treated and which has been given the treatment of one group. In this research the sample have taken as 20 students. Data collection used a technique of a test, observation, masterpiece. Learning model indoor and outdoor learning learning in group B Kindergarten Sartiasari of Surabaya there are significant differences between the results and (pre-test pos-test) \% namely 95, obtained tcount 16,83 while 2,093 ttable with $20 \mathrm{n}=$ which means hypothesis null (H0) rejected and the alternative hypotheses (H1) accepted. The result can give contribution in the attempt of enhancing teaching quality in early childhood education.
\end{abstract}

Keywords: outdoor learning, creativity

\section{INTRODUCTION}

Early childhood education (ECD=PAUD) is the level of education before primary education which is an approach to development that is intended for children from birth up to the age of six years are accomplished by providing stimulation of education to help the growth and development of the physical and spiritual so that children have the readiness to enter further education, which was held in formal, non-formal and informal.

How to study early childhood is learning while playing different to the way children learn elementary junior high or high school. The world's children are unique, surprising, dynamic, inquisitive, always exploring, the world playing and learning, always growing along with the development and growth of individual children, a child's world is full of color, it is very unfortunate that pass away only, not filled with good direction and guidance to them (Susanto, 2011:1-2)

Children's learning process also affects the learning outcomes in children. And as a professional teacher in charge to prepare the right way to provide guidance in the process of learning in children, so that children can devote his ability to learn and teachers have to understand the situation of the conditions under which children are learning. Learning outcomes are also influenced by the opportunity given to children (Abdurrahman 2012: 26-28)

Environmental factors influence the development of children, which is to be created and then used a conducive environment for conducting play. It can be done by organizing and arranging various play facilities as attractive as possible to stimulate the child's interest in participating in play activities. (Wiyani 2014: 33)

Outdoor learning models is a model of learning outside the classroom-based nature that involve direct nature to serve as a source of learning outside the classroom model-based nature initiated by Froebel and Lighart intend to bring a child to learn in the real environment so there is the opportunity to interact directly with nature.

Lendo Novo during the discussion with Munif Chatib about education politics in 2014 and 
Curriculum 2013, at the School of the Universe, he said that the real nature was the one place to learn. At the time of the child observing nature around it, in fact that is where there is learning materials (Chatib, 2013:22)

Playing is one requirement for early childhood which is very important. Basic model development program play activity consists of three main points, namely planning play activities, theme development, and classroom management switch (Outdoor Learning and Learning Indoor). Planning activities are implemented in a strategy play activities play an active, creative, and fun for children (Sujiono 2010:

71) One of the activities that draw play. Everyone as a child certainly had experience drawing, scribbling on the walls with crayons and in various other places.

Drawing as part of the art educational facilities providing freedom in the creative process execution, imaginative, expression of which is owned early childhood on the results of the drawing is often in the form of symbols, experiences in life, and whatever is done so that it has a specific meaning and can be interpreted. Each child has a different mindset with other early childhood. The idea or the idea that each child will be able to make it competitive in the future that drawing is a way of expressing human thoughts or her feelings so by drawing, feelings, ideas, ideas will communicate to other humans.

Award theme helps children to concretize verbal commands teacher. The theme was also used in early childhood learning to build knowledge in children and develop all aspects of child development. When a child is faced to draw the animal theme animals living in the soil worm or ant is an animal, a child can know as a worm or ant and all characteristics given after the real experience of the animal worms and ants before then for example the theme of animals that live in in the water that the animals fish and turtles, teachers demonstrate fish and turtles concretely so that children know the shape and color and all its characteristics.

Thematiclearning is a teaching strategy that involves several areas of development to provide a meaningful experience to children. Themes can be developed flexibly in accordance with the developmental needs of children so as not to cause boredom. (Sujiono 2010: 75-76)

This study was limited in scope and limitation of the study follows 1) Researchers looked only at the early childhood group B with age between 5-6 years; 2) Research focused on thematic drawing a distinction between the activities and creativity carried on outside the classroom (outdoor learning) and in the classroom (indoor learning).

Formulation of the problem in this research is 1) Are there differences in the level of creativity of children in the indoor and outdoor learning? 2) How different of children's creativity in the indoor and outdoor learning?.

This study was designed with one group pretest-post test design that experiments done before the treated and which has been given the treatment of one group. Pre-test (indoor) and post-test (outdoor). The aim is to tell the difference of study result of the children with use the model outdoor learning and indoor learning in groups B TK Sartiasari Surabaya.

The hypothesis tested in this study is: "No difference in the level of creativity of children in the indoor and outdoor learning.

The results showed that there are differences in the level of creativity of children in the indoor and outdoor learning. Outdoor learning indicate the level of creativity of children is higher than the outdoor learning.

\section{LITERATURE REVIEW}

Creativity is a very broad concept so difficult to formulate proper understanding. Creativity as the ability to understand the world, to interpret the experience and solve problems in a way that is new and original, the ability of individuals to produce something (result) that are new or original, or solving a problem. Creativity is a divergent thinking, thinking productive, inventive thinking heuristics and lateral thinking.

(Http://www.galeripustaka.com/2013/03/penger tian-kreativitas.html)

According Musfiroh (2003) creativity in children has its own characteristics marked by the uniqueness of the idea and the growth of imagination and fantasy. Children who are sensitive creative to stimulation, is not limited by any frames. They have the freedom, flexibility and fun activities. Creativity also helps kids be more confident, develop social skills, and learn better (Margarita Tartakovsky, M.S., 2012)

Creativity can be enhanced by applying 9 ways that can be done to support the creativity of children (Tartakovsky). 1) designing a space for creative activities; 2) conduct that is simple and easy to elaborate activities.; 3) Give them "free time."; 4) help develop children's sense of creativity by exposing the child's imagination; 5) Discuss 
creativity result by ask them about their best ideas or most creative moments; 6) Cultivate creative critical thinking to solve the problems by ask them how they approach certain problems and how they might do things differently; 7) Avoid managing. Avoid too much interference because children have a remarkable ability for creativity. Children have an amazing innate ability to be creative. 8) Help kids pursue their passions by providing the material they need; 9) Take the time for your own creativity. Accompany children in creativity like drawing, building, or coloring.

Children's creativity can also be enhanced through 8 steps. (http://www.wikihow.com):

1) Allow for your child to make simple choices, such as what to eat for dinner or where to go on a weekend. This encourages them to think independently, exercising an important aspect of creativity.

2) Encourage independence from caregivers and media. A child that is constantly entertained by others or the television will struggle to find things to do on their own without access to media.

3) Provide items in your child's environment to stimulate their imagination. Drawing supplies, blocks, books, and random craft supplies can all contribute to elaborate dramatic play schemes.

4) Brainstorm different uses for items with your child. For example, a cardboard tube can be a telescope, tower, or person. Validate all of your child's ideas, praising him or her for such an impressive imagination.

5) Ask your child open-ended questions to stretch their understanding and help them to postulate ideas.

a. Ask your child "what if" questions. "What if people could fly?" "What if people lived in space?" "What if dolphins walked on land?"

b. Involve your child in figuring out ways to make an improvement upon something. "How can we clean up the living room faster?" "How could we get water to the flowers without spilling any?" "What could we do to make the ball bounce higher?"

c. Being read a book is an excellent opportunity for a child to exercise their creativity. Ask your child what could happen next, or how a character feels (and why).
6) Play with your child. Work together to establish dramatic play scenarios, using substitute items for props when needed. Pretend play allows for children to imagine life from a different perspective, an important building block of creativity.

7) Be prepared for "messy play." While it may seem that your child is playing in the mud simply to make more work for you, in fact there is a great deal that is learned by playing with such things. When they are finished playing, make it a rule that they have to help clean up. If faced with the choice of getting messy then cleaning it up and not getting messy at all, almost all children will choose the former option.

8) Engage in story telling. Start a story and take turns building upon it. Follow your child's lead in what the mood of the story should be. Expect most stories to be more on the silly, impossible side. Since this is just a story, no idea is too far-fetched.

Examples of creativity in the visual: drawing according to imagination, give color desire, drawing in accordance perception, shadow play (Musfiroh, 2003)

Indoor learning is learning that takes place in the classroom by managing all learning facilities in accordance with the needs of children. Kids pour out all the ideas or creativity in the classroom. Learning is beneficial for teachers and children in: 1) easy to be able to arrange peace of child; 2) Child easier to pay attention to the teacher to speak in front of the class; 3) Teacher easier to prepare teaching preparation; 4) Children are not easily tired; 5) Teachers are not difficult to find learning materials. Nevertheless indoor learning have a weakness in terms of: 1) Children are more easily bored in the learning process; 2) Child is hard to imagine; 3) Children in difficult to develop learning outcomes; 4) Lessons are conducted by teachers to children is not innovative; 5) The experience received by children and teachers a little.

Indoor Learning Steps Learning in early childhood education: 1) Teachers must prepare the children's learning activities in advance by defining the themes to be taught today. For example with the theme of pets; 2) Before the learning process will start teachers must prepare students to line up before entering in the classroom; 3)Teacher allow children to sit in its place; 4) The teacher explains the learning material that has been prepared with the media there is no learning in the classroom; 5) Children were given questions about the material 
that has been described; 6) Giving the task to children such as drawing in Student's Work Sheet (Indonesian: LKS) while sitting in its place: 7) Assessment granted in accordance with the child's performance. Outdoor learning is also known by various terms such as outdoor activities, outdoor study, field study or learning outside the classroom. According to Barlet (in Husamah, 2013:20) outdoor education learning model is a study conducted outside the room or outside the classroom.

Husamah (2013:20) states, education outside the classroom is defined as education that goes beyond the classroom involving experience that requires the participation of students to follow the adventure challenge that became the basis of activities outside the classroom such as hiking, mountain climbing, camping, and others.

So, outdoor learning is an activity outside the classroom that makes interesting and fun, can be done anywhere with emphasis on the learning process is based on real facts, the matter of learning directly experienced to build meaning or impression in the memories of children.

Husamah (2013: 25) states the benefits of learning outside the classroom include: 1) Mind clearer; 2) Learning to be enjoyable: 3) Learning more varied; 4) Learning more real; 5) Children are more familiar with the real world and wide; 6) Embedded image that the world as a classroom; 7) Vehicle learning will be more widely; 8) Work more relaxed brain.

The Outdoor Learning Model Disadvantages include: 1) The learning activities are less prepared in advance that cause no time students were taken to the destination does not perform the expected learning activities so that there is the impression of playfulness; 2) There is an impression that the activities of teachers and students learn about the environment require a long time to spend time learning in the classroom; 3 ) The narrowness of view of the teachers that learning only occurs in the classroom.

Many things need to be considered by the teacher. One is the outdoor learning will be the main attraction so many people who came to watch. Cynosure students will be immediately drawn anywhere because of their position in the open learning. Therefore, as a teacher is smart, required certain tips to overcome the disadvantages of outdoor learning.

\section{METHODS}

This research is a quantitative approach to one group pretest-posttest design that experiments conducted before the treated and which has been given the treatment of one group. Pretest $(\mathrm{O} 1)$ is done in indoor learning activities, while the post-test $(\mathrm{O} 2)$ is performed after the outdoor learning. Schematically can be described by the sign test activities (O2-O1) Sugiyono (2013: 110).

This study did not use sampling for number of children as subjects only 20 . So that all children are involved as research subjects. Data were collected through a performance test. The performance test used to determine the development of children's creativity by using observation sheet performance. The results of performance observations are matched with the children's work in order to obtain accurate data on the level of creativity of children. The level of creativity of children include: level 1 (underdeveloped), level 2 (start growing), level 3 (develop according to expectations), level 4 (developed very good).

Data analysis procedure involves three steps: 1) Preparation, 2) Tabulation, 3) The application of data analysis techniques in accordance with the research design. (Arikunto, 2013: 278).

Analysis of the results of the experiment that is testing the hypothesis that using pre-test and posttest one group design, the $\mathrm{t}$ test.

\section{RESULTS AND DISCUSSION}

Before the test the hypothesis, first conducted an analysis of the data based on the tabulation of data collection as in the following table. 
Table 1. Tabulation Results Creativity Drawing Thematic Learning.

\begin{tabular}{|c|c|c|c|}
\hline Subjesl & Preiest & Post last & $\begin{array}{l}\text { Gaun (d) (Pust- } \\
\text { est Ple-lest) }\end{array}$ \\
\hline 1 & 9 & 13 & 4 \\
\hline 2 & 8 & 13 & 5 \\
\hline 3 & 8 & 13 & 5 \\
\hline 4 & 9 & 14 & 5 \\
\hline 5 & 10 & 16 & 6 \\
\hline 6 & 7 & 13 & 6 \\
\hline 7 & 10 & 13 & 3. \\
\hline 8 & 10 & 13 & 3 \\
\hline 9 & 10 & 15 & 5 \\
\hline 10 & 9 & 14 & 5 \\
\hline 11 & 6 & 13 & 7 \\
\hline 12 & 9 & 16 & 7 \\
\hline 13 & 8 & 13 & 5 \\
\hline 11 & 8 & 13 & 5 \\
\hline 15 & 6 & 11 & 5 \\
\hline 16 & 9 & 16 & 7 \\
\hline 17 & 8 & 11 & 3 \\
\hline 18 & 10 & 16 & 6 \\
\hline 19 & 10 & 13 & 3 \\
\hline 20 & 16 & 16 & ถ์ \\
\hline \multirow[t]{2}{*}{$N=20$} & 174 & 275 & \\
\hline & $x_{1}=\mathrm{s}, 7$ & $x_{1}=13,75$ & $\sum d=1117$ \\
\hline
\end{tabular}

The hypothesis tested in this study is: "No difference in the level of creativity of children in the indoor and outdoor learning.

Table 2. Hypothesis Testing Result

\begin{tabular}{|c|c|c|c|c|c|}
\hline hypothesis & Sigr & I count & $T_{\mathrm{rbb}}$ & $\mathrm{Ho}$ & $\mathrm{HI}$ \\
\hline No & $5 \%$ & 16,83 & 2.093 & Rejected & accepted \\
\hline ditference & $\mathrm{Db}$ & & & & \\
\hline in the & $N-1$ & & & & \\
\hline level if & $=20-1$ & & & & \\
\hline $\begin{array}{l}\text { crealivily } \\
\text { of }\end{array}$ & $=19$ & & & & \\
\hline chaldren & & & & & \\
\hline in the & & & & & \\
\hline $\begin{array}{l}\text { muloer } \\
\text { mant }\end{array}$ & & & & & \\
\hline $\begin{array}{l}\text { and } \\
\text { outdiour }\end{array}$ & & & & & \\
\hline arn & & & & & \\
\hline
\end{tabular}

So based on the above table null hypothesis is rejected and the working hypothesis accepted. The hypothesis No difference in the level of creativity of children in the indoor and outdoor learning is rejected. Alternative Hypothesis (H1) adapted. It means that there are differences in the level of creativity of children in the indoor and outdoor learning.

How about the second question "How different of children's creativity in the indoor and outdoor learning?"
The level of creativity of children in pre-test using indoor learning of 20 children is still lacking. Of the four thematic assessment indicators drawing given to children average yield that can be achieved is the ability to classify the types of animals according to the theme and coloring neatly began to develop. The results of the children's creativity are the lowest of all four assessment indicators given is that of the indicator 2 the ability to form a circular shape/corrugated using the fingers and hands. Of the 20 children who received study results with the ability to move the fingers and hands are growing expectations as many as 15 children and 5 children begin to develop, which is developing very well, 0 child while 0 the ability to draw children undeveloped. (Score of 55). of the indicators four by coloring a picture with a tidy, five children undeveloped, 11 children begin to develop in neatly coloring pictures, which developed very well 0 child and four children have been developed in accordance expectations when coloring neatly. (Score 40). Of the indicators 2, namely the ability to form a circular shape/Corrugated using fingers and hands which is growing very well, 0 child and develop according to expectations also have 2 children, who began to develop as many as 15 children, while three other children undeveloped. (Score 39).Of the 16 children indicators 3 that begins to develop can classify the types of animals according to the theme, developing according to expectations 2 children, which developed very well 0 's and 2 children undeveloped (Score 40).

Table 3.Differences between the mean level of creativity of children in the indoor and outdoor learning

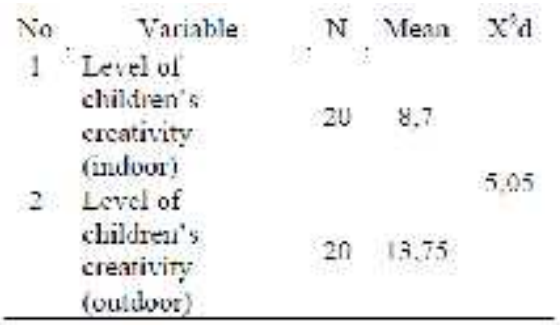

Based on the above table it is known that the average level of creativity of children in the outdoor learning higher than the level of creativity in the indoor learning.

Outdoor learning also showed good results to develop cognitive skills and creativity of children.

Amylia and Setyowati, research on the Influence of Outdoor Learning to Children's Ability of Knowing Concept of Numbers on Group A kindergarten Tunas Harapan show that outdoor 
learning affect the ability to know the number of the concept of group A Kindergarten. Nissa and Widajati Research on the Influence of Outdoor Learning Capability Model to Children Drawing Thematic Group B in kindergarten Dharma Wanita Pembangunan Randegansari shows the results of outdoor learning models significant effect on the ability to drawing thematic. Research conducted by Hasibuan and Ningrum about Effect Of Play Outdoor Activity And Finger Painting On Creativity Early Childhood indicate that playing outdoor effect on a child's creativity, as evidenced from the group that learned to use play activities outdoor creativity better than a group that is not taught using play activities outdoor.

From the description above can be said that outdoor learning can have a positive impact for children's learning outcomes, both in cognitive, logic, and creativity.

\section{CONCLUSION}

From these results it can be concluded that the differences in the level of creativity of children in learning indoor and outdor. This proved significantly from the results of hypothesis testing. Outdoor learning indicate the level of creativity of children is higher than the level of creativity in learning indoor. This is due to the influence of outdoor learning can make mind clearer, feels good, more varied, recreational, more real. In addition, children are more familiar with the real world and wide, embedded image that the world as a classroom, learning vehicle will be wider and the brain work more relaxed the results of this study recommend that outdoor learning should be more common in schools, especially at the level of early childhood education.

\section{ACKNOWLEDGEMENTS}

Upon completion of this study, the researchers express to thankyou and appreciation to Mr. Djoko Adi Walujo, Rector of the University of Adi Buana Surabaya, Mrs. Roestijah Ali Basjar, Head of kindergarten Sartiasari Surabaya, Mrs. Dwi Retnani Srinarwati, former Dean of the Faculty of Education University of Adi Buana Surabaya, the Students of Teacher Education Early Childhood Education Adi Buana University Surabaya, and pseudo-parties which has been supporting us in conducting this study. May the kindness you get rewarded goodness which doubled from a loving God.

\section{REFERENCES}

Abdurrahman, Mulyono. (2012).Anak Berkesulitan Belajar. Jakarta: Renika Cipta.

Amylia, Linda Rizca, Setyowati, Sri. (2016). Pengaruh Outdoor Learning Terhadap Kemampuan Mengenal Konsep Bilangan Anak Kelompok A

TunasHarapan.ejournal.unesa.ac.id/article/1086 7/19/article.pdf . access29/9/2016.

Arikunto, Suharsimi. (2013). Prosedur Penelitian Suatu Pendekatan Praktik. Jakarta: PT. Rineka Cipta.

Chatib, Munib, Fatimah Irma Nurul. (2013). Kelasnya Manusia.Bandung: PT Mizan Pustaka.

Hasan, Maimunah. (2009). Pendidikan Anak Usia Dini.Yogyakarta:DIVA Press.

Husamah. (2013). Outdoor Learning. Prestasi Pustaka Raya.

Hasibuan, Rachma, Ningrum, Mallevi Agustin. (2016). Pengaruh Bermain Outdoor Dan Kegiatan Finger Painting Terhadap Kreativitas Anak Usia Dini. Jurnal Pendidikan Volume 1 Nomor 1 Tahun 2016 Halaman : 72 - 80 ISSN: 2527-6891

Nissa, Heppy Zakiatun, Widajati, Wiwik.(201). Pengaruh Outdoor Learning Terhadap Kemampuan Mengenal Konsep Bilangan Anak Kelompok A

TunasHarapan.ejournal.unesa.ac.id/article/1091 7/19/article.pdf. access29/9/2016.

Margarita Tartakovsky, M.S. 9 Ways to Support Your Child's Creativity. http://psychcentral.com/blog/archives/2012/03/ $13 / 9$-ways-to-support-your-childs-creativity/ access 29/9/2016

Musfiroh (2003). Kreativitas Anak Usia Dini Dan Implikasinya Dalam Pendidikan. Makalah Disajikan di hadapan guru-guru Play Group dan TK Kreatif PRIMAGAMA, di PPPG Matematika, Rabu, 9 Juli 2003.

Sugiyono. 2010. Metode Penelitian Pendidikan. Bandung: Alfabeta.

Susanto Ahmad. 2011. Perkembangan Anak Usia Dini. Jakarta: Kencana Prenada Media Group.

Wiyani, Novan, Ardy. (2014). Psikologi Perkembangan Anak Usia Dini. Yogyakarta: Gava Media.

http://academia.edu/9586327/Pembelajaran_Luar_ kelas_Out_DoorStudy_Pengertian Pembelajaran Indoor Learning.Diakses/diunduh,6 November 2015 pukul 09.00 
http://www.wikihow.com/Develop-Child-

Creativity. access 29/9/2016

http://artfulparent.com/2012/07/how-to-encourage-

drawing-skills-confidence-creativity-in-young-

children.html access 29/9/2016

http://www.galeripustaka.com/2013/03/pengertian-

kreativitas.html access 29/9/2016 